Vesna Tornjanski $^{1}$
Sanja Marinković
Maja Levi Jakšić
Vesna Bogojević Arsić
JEL: 031, C83, D70, G21

DOI: 10.5937/industrija43-8074

UDC: 005.342:336.71

005.311.11/.12

Original Scientific Paper

\title{
The prioritization of open innovation determinants in banking
}

Article history:

Received:15 April 2015

Sent for revision: 15 May 2015

Received in revised form: 28 July 2015

Accepted: 23 August 2015

Available online: 15 October 2015

\begin{abstract}
The research scope of the paper is prioritization of open innovation determinants in banking industry using an integrated application of qualitative and quantitative methods in the evaluation process. The research methods were implemented to compound the depth of experts' knowledge and experience on the one hand, and the precise mathematical reasoning, on the other, thus creating the objective and accurate basis for effective decision making. The overview of determinants of open innovations in banking industry has been obtained from the literature overview and the Delphi study conducted among 51 experts from banks in Serbia. Fifteen significant determinants within five dimensions were further evaluated through AHP decision-making method to prioritize them toward the development of the open innovation in banking. The research results show that effective application of open innovation in banking lies in formal reinforcement by management to integrate innovation into organizational policies and in designing dual structures that facilitate the initiation and implementation of an innovation, i.e. building an ambidextrous organization. The research findings and results introduced in this paper can be usefully applied and widely used by both academics and practitioners who are interested in applying the open innovation concept in banking industry.
\end{abstract}

Keywords: Innovation, open innovation, banking, Delphi and AHP method, innovation determinants

\footnotetext{
${ }^{1}$ Eurobank a.d. Belgrade

${ }^{2}$ University of Belgrade, Faculty of Organizational Sciences, marinkovic.sanja@fon.bg.ac.rs

${ }^{3}$ University of Belgrade, Faculty of Organizational Sciences

${ }^{4}$ University of Belgrade, Faculty of Organizational Sciences 


\section{Prioritizacija determinanti otvorenih inovacija u bankarstvu}

Apstrakt: Istraživački okvir rada predstavlja određivanje prioriteta determinanti otvorenih inovacija u bankarskom sektoru uz integrisanu primenu kvalitativnih i kvantitativnih metoda u procesu evaluacije. Primenjene metode istraživanja imaju za cilj da objedine znanje $i$ iskustvo stručnjaka, sa jedne strane, i precizno matematičko rezonovanje, sa druge, čime se stvara objektivna $i$ pouzdana osnova za efektivno odlučivanje. Determinante otvorenih inovacija su izvedene na osnovu istraživanja literature $i$ sprovedene Delfi studije koja je obuhvatila 51 stručnjaka iz banaka na teritoriji Srbije. Petnaest značajnih determinanti u okviru pet dimenzija su zatim evaluirane kroz AHP - metod za podršku odlučivanju, kako bi se odredio prioritet determinanti u cilju razvoja koncepta otvorenih inovacija u bankarstvu. Rezultati istraživanja pokazuju da se efektivna primena otvorenih inovacija $u$ bankarstvu zasniva na formalnom jačanju pod uticajem menadžmenta, kako bi se inovacije integrisale u politiku organizacije, kao i na kreiranju dualne strukture koja podstiče pokretanje i uvođenje inovacija, tj. na izgradnji dualne (engl. ambidextrous) organizacije. Saznanja dobijena istraživanjem $i$ predstavljeni rezultati u ovom radu mogu biti široko primenjeni i korišćeni od strane stručnjanka iz nauke i prakse koji su zainteresovani za primenu koncepta otvorenih inovacija u bankarskom sektoru.

Ključne reči: Inovacije, otvorene inovacije, bankarstvo, Delfi i AHP metod, determinante inovacija

\section{Introduction}

Innovation has always played a vital role in predicting a long-term survival and development of organizations in all industries. Innovation encompasses a mixture of knowledge and actions that results in new products, services, processes, input and output markets, or organizations (Sundbo, 2003), which implies organizational, managerial and technical innovations, new markets, financial innovations and new combinations (Heertje \& Perlman, 1991). Innovations represent one of the competitive forces of an organization. Moreover, innovations have been identified as a key driver for organizations to prosper, grow and sustain high profitability (Drucker, 1988; Christensen, 1997). According to Luftenegger et al., (2010, p.1.), "most companies are using innovation to sustain their business models". Considering innovation as a notion, Rogers (1995) stated that innovation represents an idea, object or practice experienced as new by individual or other units of adoption.

Today's highly competitive marketplace, characterized by global economic integration into volatile business environment, shorter innovation and product 
life cycles, rapid growth of information technologies and electronic communication, puts pressure on companies to innovate constantly. A recently proposed and advocated concept of innovation management is a concept of open innovation, recognized as a key driver of sustainable growth for most companies in all industries (Gassmann \& Enkel, 2004). This new paradigm has become increasingly important for both academics and practitioners over recent years (Alguezaui \& Filieri, 2010; Bahemia \& Squire, 2010; Chesbrough \& Appleyard, 2007; Chiaroni et al., 2011).The "open innovation" as a notion was initially proposed by (Chesbrough, 2003) and soon attracted the interest of managers / practitioners and scientists / researchers. Chesbrough (2003) stated that internal research and development are not sufficiently valuable strategic assets due to changes in society and industry, which led to the increased mobility of knowledge and the development of new financial structures, which ultimately resulted in the need for a new innovation model - open innovation model.

Open innovation is defined as "the use of purposive inflows and outflows of knowledge to accelerate internal innovation, and expand the markets for external use of innovation, respectively" (Chesbrough et al., 2006, p.1). Additionally, Chesbrough et al. (2006) defines open innovation as "a paradigm that assumes that firms can and should use external ideas as well as internal ideas, and internal and external paths to market, as they look to advance their technology" (Chesbrough et al., 2006, p.1). The concept of open innovation is based on an organization's need to open up innovation processes and to put together internally and externally developed technologies, ideas and knowledge in order to create business value (Fredberg et al., 2008). Furthermore, the open innovation paradigm also assumes that internal ideas can be placed into the market using external channels, outside of current company's businesses, in order to generate additional value for the business (Chesbrough et al., 2006). Open innovation as a new business paradigm represents a mindset characterized by customer integration, flexibility and openness. Moreover, authors emphasize open innovation is the best way of value creating and is vital for operational excellence and profitable growth (Fasnacht, 2009; Schmitt et al., 2013; Wiengarten et al., 2013). Further, the model suggests that companies have to interact with various types of partners to acquire knowledge, ideas and resources from the external environment in order to remain competitive in the open market. (Chesbrough, 2003; Laursen \& Salter, 2006; Dahlander \& Gann, 2010). Besides, it represents a change in generating and managing intellectual property. Open innovation is a holistic approach to innovation management as "systematically encouraging and every innovator exploring a wide range of internal and external sources for innovation opportunities, consciously integrating that exploration with a firm's capabilities and resources, and broadly exploiting those opportunities through multiple channels" (West \& Gallagher, 2006, p.1). Enkel and Gassmann 
(2007) suggest how an open innovation may be practiced. According to the authors, open innovation involves: integration of suppliers and customers, collecting ideas, implementing innovation across industries, purchasing intellectual properties and investing in the global knowledge foundation.

To introduce open innovation in banking industry it is important to get clear and unambiguous insights into key determinants of innovations, which should underlie an appropriate strategy for successful open innovation concept in banking. The overview of determinants of innovations in banking industry has been obtained from the literature overview and the Delphi study conducted among experts from banks in Serbia. The Delphi study was intended to achieve consensus among experts from the banking industry on determinants identified from the literature overview. Significant determinants were further evaluated through the AHP decision-making model to prioritize the determinants in the implementation of the open innovation concept in banking.

The aim of this paper is to find out the key determinants for successful implementation of an open innovation concept in the banking industry. The purpose of this paper is to demonstrate and advocate the importance of open innovation in the banking industry as a key success factor for sustainable growth and development of the banking industry in the $21^{\text {st }}$ century.

\section{Open innovation in financial service sector}

Over the recent years, financial service industry has been in the revolutionary transformation process triggered by a number of new developments in economies, market growth, regulations, customer demands, technology, policies and demographic changes. These underlying influences are always evolving. However, efficient growth strategies, creation of value for the customers and shareholders have always been challenges for financial companies, not only during periods of growth, but also during volatile times. In order to react to long-term directions and short-term occurrences, financial companies have to develop the ability to tailor and promptly implement the appropriate transition strategies (Fasnacht, 2009; Huo \& Hong, 2013).

Transition strategy towards an open innovation model encompasses open, flexible and service oriented business models that integrate customers, moreover, put customers in the center of business focus through appropriate architecture and business strategies (Enkel et al., 2009; Fasnacht, 2009; Tornjanski et al., 2014; Teece, 2010).

A shift in the transformation from a traditional organization which is characterized by hierarchical, bureaucratic structures with a product-oriented function, into an organization that follows principles of flexibility, openness and 
customer-oriented function represents a challenging drive for managers in financial services. Knowing this, competitive advantage may be achieved if the management in financial sector understands what they have to provide, how they will leverage resources and capabilities as an integrated system. Growth and innovation strategies should be flexible enough in order to properly respond to changes. More importantly, building and strengthening trust, as it becomes increasingly important in an interconnected world, within an organization and external stakeholders, such as customers and business partners, require the generation of new ideas and set of new management practices and dynamic set of management capabilities and skills (Chesbrough et al., 2006; Enkel et al., 2009; Fasnacht, 2009; Teece, 2010; Tornjanski et al., 2014). Dynamic management should establish closer relationships with a broader range of stakeholders with the trust that represents just one promising approach in the open innovation model (Fasnacht, 2009; Mol \& Birkinshaw, 2009; Tornjanski et al., 2014).

Furthermore, the integration of employees' intellectual capital into an open innovation model and organizational ability to provide supportive business culture and buy-in climate towards open innovation are essential. In contrast, inability and unsupportive organizational culture are the greatest barriers to innovation and profitable growth. Hence, employees and customers are two most valuable assets of the business. Building learning and innovative culture within an organization results in better performance than through a traditional model, which is characterized by closed command and control system (Fasnacht, 2009; Gassmann et al., 2010; Martins \& Terblanche, 2003). Open innovation model emphasizes that financial organizations have to improve and intensify partnerships with external stakeholders and universities. Developing a new brand of innovative management and collaboration in financial services and universities is required in order to respond to all changes and challenges coming into this area (Fasnacht, 2009; Huff et al., 2013).

Frequent changes in the financial service industry imply new forms of innovation management. Accordingly, traditional and closed approaches to innovation are proved to be insufficient to manage successfully these changes. The financial sector has to understand what and why it needs to change and how to adapt to the new rules of an open innovation paradigm (Fasnacht, 2009).

\subsection{Open innovation in real-life practice}

Not many companies followed a fully closed innovation model in practice, but many of them started to implement open innovation model as a requirement to adapt to changes occurring in the external environment (Chesbrough, 2003). "In a world of mobile workers, abundant venture capital, widely 
distributed knowledge and reduced product life cycles, most enterprises can no longer afford to innovate on their own" (Van de Vrande et al., 2009, p. 426).

Trends such as company's agility, flexibility and outsourcing have already put pressure on organizations to revise their own strategies and processes and to become network organizations. "The do-it-yourself" mentality innovation management just became outdated (Gassman, 2006). Yet, plenty of developments and consolidations in the innovation arena have led to a requirement for organizations to make innovation processes more and more open. Moreover, Koschatzky (2001) explains that companies which do not exchange knowledge and which do not collaborate minimize the knowledge development in long term and minimize the ability to engage into exchange relations with other companies. Hence, the cooperation with external stakeholders is essential to increase innovativeness and reduce the time to enter a market (Enkel et al., 2009).

Executive managers in many companies have considered the next step towards open innovation. One way is pursuing collaboration between innovation management and networks of suppliers, customers and independent specialists who interact with each other in the development process or projects. With such strategy, an organization could come up with better ideas for new products and services; a company will be able to develop these ideas in more efficient and cheaper way, spending less time in launching products / projects into the market, which is of a paramount importance taking into account very competitive business environment (Bughin et al., 2008).

A common requirement in an open innovation approach is extensive empirical research, testing and development, independent of the business industry. Yet, understanding of prospective differences in an open innovation across different industries is of a high importance to managers who deal with changes in respect to innovation (Dodgson et al., 2006).

It is evident that an open innovation era has begun for many companies in various industries, but still there is no clear understanding of the mechanisms how to entirely profit from the approach (Enkel et al., 2009) which should be taken into account for further evaluation and testing in real-life practice. According to Enkel et al. (2009) real - life business is not based on sheer open innovation approach but rather on company's simultaneous investments in closed and open innovation activities.

However, there are still many issues related to open innovation approach that should be understood better in order to completely absorb this concept into practice. Also, there is still a lack of knowledge when and how to do it (Huizingh, 2011). 
Generally, an open innovation paradigm has proved to be a beneficial model for many companies in various contexts. As Huizingh $(2011$, p. 8) stated: "open innovation is on its way to become an innovation".

\subsection{Changes in financial services and banking}

Development of services in the modern economy requires a wide range of technological expertise that is very often above the expertise level of service providers. Therefore, the innovation processes in services increasingly imply connections, linkages and cooperation of several organizations in different stages of the new service development (NSD) process (Marinkovic et al., 2011).

The financial services sector has a significant role in the modern world economy. The financial institutions that constitute an economy's financial system represent the brain of the economy's ensuring the most of the economy's requisites for many operations. Moreover, financial services sector is a significant contributor to the GDP and employment (WTO, 2013). The financial services sector participates with about $8 \%$ of the gross domestic product (GDP) and about $4 \%$ of employment in the services sector of the Organization for Economic Cooperation and Development countries (OECD, 2008).

The financial economy has changed substantially since the 20s century along with the evolution and development of companies and markets (Leire et al., 2013). The financial service sector has been obliged to rethink the intermediaries' role. Furthermore, in recent years the financial industry has changed the structure of the organization, which has created the strategic turbulence in financial institutions. Not so many industries have encountered as much "strategic turbulence" as the financial service industry. Searching for the response to comprehensive technological and regulatory changes, significant shift in customer requirements as well as globalization, the financial services face profoundly displaced organizational structures with a great deal of uncertain future (Walter, 2009). These new trends in economic environment require the financial services sector to innovate, revise business models and revitalize the trust of customers in financial institutions in order to achieve long-term sustainable growth (Luftenegger et al., 2010).

The globalization phenomena in the financial services foster more efficient financial techniques in financial markets, which provide more competitive advantages to financial companies that compete worldwide. Moreover, regulation of national and international markets, liberalization policies and advancement of information and communication technologies bring contribution to the global financial system functioning (Leire et al., 2013). The developing and emerging markets worldwide provide a various opportunities 
such as unlimited workforce, high gross domestic product growth and massive potential of consumers (Fasnacht, 2009). Moreover, it has been argued that the economic potential of developing and emerging countries, particularly of BRIC economies may have a dominant role in the global economic system by the year 2050, "with China surpassing the United States in output by 2035 year" (Luthans \& Doh, 2011, p.12).

"Economic integration and the rapid growth of emerging markets are creating a shifting international economic landscape" in the $21^{\text {st }}$ century (Luthans \& Doh, 2011, p. 12). Internationalization and globalization have become a very narrow focus of strategic management in various business industries which are influenced by these phenomena.

Banking industry represents the main part of financial services (Fasnacht, 2009) and "banks play a vital role in the economy of any country" (Mihailovic, 2009 , p. 1). In Serbia, banking sector dominates in the financial system and accounts for $92.4 \%$ in the total financial sector. As such, it represents the main contributor to Serbian financial system stability (NBS, 2013).

The banking industry has been a conservative industry, very resistant to change. The past was characterized by stable environment and industry structure, clear business models and defined boundaries that made linear and predictable business and business environment resulting in the slower pace of innovation, compared to other industries. Yet, the conditions have changed over the last 20 years, which has led to significant changes in the banking industry (Fasnacht, 2009).

Today, the banking industry is undergoing a period of transformation and consolidation due to changes in technology, customer requirements, market share and competition (Frei et al., 1997). "In the past 30 years innovation processes in banking industry resulted in tremendous developments of services and products due to digitalization era. This developing process is a never ending story, innovations underlie the success. Apart from the benefits that banking sector gained in this era, IT gained a lot, since banking industry was in the driving seat in many segments. In the years to come I expect that new technologies and innovations from other segments of human development will equally keep the pace in the banking industry" ${ }^{\prime \prime}$.

Direct drivers for growth in banking are innovations in services, products and processes. Reciprocal dependence of innovation, knowledge and growth open up the opportunities to a creation of an open innovation model in the banking industry. Overall, sustainable growth in the banking industry can be

\footnotetext{
${ }^{5}$ Pivić, M., (Top manager in Serbian banking with more than 9 years of banking experience at managerial position) commented in Delphi questionnaire related to the paper The prioritization of open innovation determinants in banking, 2013).
} 
achieved only through constant monitoring the risks connected to growth strategies and innovation (Fasnacht, 2009; Cooke, 2013).

\section{Research framework and methodology}

\subsection{The Delphi method}

Based on the broader literature review (e.g. Martins \& Terblanche, 2003; Chesbrough, 2006; Gassmann, 2006; West \& Gallagher, 2006; Chesbrough, 2007; Chesbrough \& Appleyard, 2007; Sarros et al., 2008; Elmquist, 2009; Enkel et al., 2009; Fasnacht, 2009; Van de Vrande et al., 2009; Chesbrough, 2010; Wallin \& Von Krogh, 2010; Zott et al., 2011; Bellantuono et al., 2013), sixty one (61) open determinants are obtained and grouped into eight (8) dimensions by the authors of the paper in order to prioritize them. Relevant dimensions of determinants for successful implementation of an open innovation in banking industry encompasses organizational context, business model and strategy, leadership and culture, intellectual property (IP), collaboration, customer and products, technology and infrastructure, and process innovation.

The Delphi method was then used to recognize the most significant elements for further evaluation which was done afterwards through the AHP approach. The overall aim was to select the most significant determinants and make the priority in the implementation of an open innovation concept in the banking industry.

The Delphi method is one of a widely used qualitative research methods with quantitative elements which uses the advantages of group opinion. The Delphi method is also an exploratory and intuitive method in which the subjective evaluation of selected experts on particular issues plays an important role. Using the method in a rational and systematic manner, professional knowledge, experience and intuition of experts, come to the fore (Okoli \& Pawlowski, 2004; Skulmoski et al., 2007). According to Bhuasiri et al. (2012), effectiveness of decision making could be achieved by consensus using the Delphi method.

The Delphi method, as a method of qualitative research, has been chosen in order to collect experts' judgments in a group decision making setting. Research sample was then selected - a critical component in the research methodology is selecting research participants since experts' opinions represent the output of the Delphi.

There are several requirements that imply "expertise": "i) knowledge and experience with the issues under investigation; ii) capacity and willingness to 
participate; iii) sufficient time to participate in the Delphi; and, iv) effective communication skills" (Adler, 1996; Skulmoski et al., 2007). Therefore, expertise is needed for the selection of people who are able to answer the research questions.

The analysis of round 1 implies derivation of results of round one using statistical calculations. In round 2 of the Delphi, the experts involved in the research have insight into the results of the answers in round 1, therefore, they have the opportunity to revise their initial opinions and to consolidate them with others or to leave them the same. Each following round should result in achieving consensus among experts involved in the research project.

\subsection{The AHP: multi-criteria decision support method}

The Analytic Hierarchy Process is one of most extensively and widely used decision-making method developed by T. Saaty in the 1970s (De Felice \& Petrillo, 2010; Krishnan et al., 2012) to provide a "framework for solving different types of multi-criterion decision problems based on the relative priorities assigned to each criterion's role in achieving the stated objective" (Handfield et al., 2002, p.75). In addition, the AHP method provides the measurement of consistency of decision makers' collected data (Taleai \& Mansourian, 2008).

The AHP is a comprehensive and logical framework, designed to choose the best from a given alternatives evaluated in regard to defined criteria, by allowing decision-makers to structure the complicated problems in a hierarchical model that encompasses the main goal, criteria, sub-criteria, alternatives and the relationship among them (De Felice \& Petrillo, 2010).

The main advantage of the AHP approach is its ability to model a complex, "multiattribute, multiperson and multiperiod problem hierarchically" (Sari et al., 2008, p. 370). Moreover, the AHP provides a mixture of both, qualitative and quantitative attributes (Peng et al., 2013). The further strength of the model lies in its ability to recognize inconsistent judgments (Sari et al., 2008; Chen, 2006).

The AHP represents a mixture of knowledge, experience, individual judgments and opinion in a logical and systematical way. Moreover, the model has a very large range of application in decision making such as cost benefit analysis, investment priorities, resource allocation, forecasting, benchmarking, prioritization, ranking, technology management, quality management, strategic management where the decision is of far-reaching importance. In addition, the AHP is used to solve many decision support problems effectively such as quality control system, supplier selection, evaluation and technology selection alternatives (De Felice \& Petrillo, 2010). 
According to Saaty $(1980,1986)$, the AHP is based on the four axioms and three primary principles. The proposed axioms underlying AHP are: 1) reciprocal axiom; 2) homogeneity axiom; 3) dependence axiom and 4) axiom of expectations. The AHP is, also, based on the three primary principles: 1) decomposition; 2) comparative judgments and 3) synthesis (Saaty, 1980; Harker \& Vargas, 1987; Chen, 2006; Sari et al., 2008; Arslan, 2009). The decomposition principles assume designing a decision problem into a hierarchy that includes the overall goal at level 0 , criteria $(C 1, C 2, \ldots, C n)$, at level 1, sub criteria $(C 1.1, C 1.2, \ldots, C n . k)$ at level 2 and alternatives ( $A 1$, $A 2, \ldots, A m$ ) at level 3 (Chen, 2006).

Applying the principle of comparative judgment, "the users set up a comparison matrix at each level by comparing pairs of criteria, or pairs of alternatives at the lowest level" (Sari et al., 2008, p. 370) according to Saaty's scale, in which ranking of 1 signifies equal importance between two elements, while a ranking of 9 indicates the absolute importance of one of the elements which is being compared (De Felice \& Petrillo, 2010; Sari et al., 2008). In the model it is necessary to have $n *(n-1) / 2$ comparisons.

"Once the matrix of pairwise comparisons has been developed, one can estimate the relative priority for each of the alternatives in terms of the specific criteria. Preferences derived from a criteria or sub criteria matrix are used to calculate a composite weight for each alternative. This part of the AHP is referred to as synthesis. This enables the AHP to obtain not only the rank order of the alternatives, but also their relative standings measured on a ratio scale. The alternative with the highest overall rating is usually chosen as a final solution" (Sari et al., 2008, p. 370).

In pairwise comparison method, the elements in each level are compared in pairs with regard to its significance to a given element in higher levels of the hierarchy (Alonso \& Lamata, 2006). The results of pairwise comparisons at each level of hierarchy give a square matrix $A$, where elements are given by aij=wi/wj, articulating the predominance of $i$ in respect to $j$, expressed in the Saaty's scale (De Felice \& Petrillo, 2010). The comparison results could be presented with a matrix.

$A=[\mathrm{aij}] \mathrm{n} * \mathrm{n}$

Where

$n$ is the number of decision elements.

The matrix A should meet two conditions:

i) aij $>0$

ii) aji=1/aij 
The yields of $n \star n$ matrix $A$ are:

$$
A=\left(a_{i j}\right)=\left[\begin{array}{cccc}
w_{1} / w_{1} & w_{1} / w_{2} & \ldots & w_{1} / w_{n} \\
w_{2} / w_{1} & w_{2} / w_{2} & \ldots & \vdots \\
& \ddots & \cdots & \vdots \\
w_{n} / w_{1} & w_{n} / w_{2} & \cdots & w_{n} / w_{n}
\end{array}\right]
$$

Once all pairwise comparison matrixes are developed, the vector of weights, $w=[w 1, w 2, \ldots, w n]$, is calculated based on the Saaty's eigenvector procedure that includes two steps. "First, the pair-wise comparison matrix, $A=\left[\right.$ aij] $n{ }^{\star} n$, is normalized" (Chen, 2006, p. 169) by equation (3). Second, the weights are calculated by equation (4) (Chen, 2006).

Normalization:

$$
a_{i j}^{*}=\frac{a_{i j}}{\sum_{i=1}^{n} a_{i j}}
$$

Where $j=1,2,3, \ldots, \mathrm{n}$
Weight calculation:

$$
w_{i}=\frac{\sum_{j=1}^{n} a_{i j}^{*}}{n}
$$

Where $i=1,2,3, \ldots, \mathrm{n}$

According to Saaty (1980), "there is a relationship between the vector weights, $w$, and the pairwise comparison matrix, $A$ " (Chen, 2006, p. 169), as equation (5) shows.

$A \omega=\lambda \max W$

"The Amax value is an important validating parameter in the AHP and is used as a reference index to screen information by calculating the consistency ratio (CR) of the estimated vector. To calculate the $C R$, the consistency index $(\mathrm{Cl})$ for each matrix of order $n$ can be obtained" (Chen, 2006, p. 169) from the following equation.

$$
\mathrm{CI}=\frac{\lambda \max -n}{n-1}
$$

Next, the consistency ratio (CR) is derived using the following equation:

$$
\mathrm{CR}=\frac{C I}{R I}
$$

Where 
$R I$ is a random consistency index.

The consistency ratio (CR) is obtained by comparing the consistency index (CI) with the corresponding value from Table 1, provided by Saaty (1986) "each of which is an average random consistency index derived from a sample of randomly generated reciprocal matrices" (Domański \& Kondrasiuk, 2005, p. 437).

Table 1. Average Random Consistency Index (RI)

\begin{tabular}{l|llllllllll}
\hline $\mathbf{N}$ & $\mathbf{1}$ & $\mathbf{2}$ & $\mathbf{3}$ & $\mathbf{4}$ & $\mathbf{5}$ & $\mathbf{6}$ & $\mathbf{7}$ & $\mathbf{8}$ & $\mathbf{9}$ & $\mathbf{1 0}$ \\
\hline $\begin{array}{l}\text { Random } \\
\text { consistency } \\
\text { index (RI) }\end{array}$ & 0.00 & 0.00 & 0.58 & 0.90 & 1.12 & 1.24 & 1.32 & 1.41 & 1.45 & 1.49 \\
\hline
\end{tabular}

Source: Saaty, 1986

According to Saaty (1986), Table 1 depicts the values of the random consistency index (RI) from matrices of order one to ten (Domański \& Kondrasiuk, 2005). "If $C R<0.1$, then the comparison is acceptable. If, however, $C R>0.1$, then the values of the ratio are indicative of inconsistent judgments. In such cases, one should reconsider and revise the original values in the pairwise comparison matrix $A^{\prime \prime}$ (Chen, 2006, p. 169).

\section{The research results and analysis}

\subsection{The application of the Delphi method in the study}

The first and second round of surveys in this study was conducted using the Delphi method in order to facilitate consensus among experts about the determinants for successful implementation of an open innovation in the banking industry, grouped into eight dimensions that are researched in a broader literature review.

This study employed web-based questionnaires and the consensus was considered adequate if $75 \%$ of the experts agreed on each determinant. The same experts participated in round one and round two of the Delphi. The banking experts from Serbia were asked to rank the importance of determinants for a successful implementation of an open innovation model in the banking sector in which a response reflects a personal attitude based on knowledge and experience from education and practice. A five-point Likert scale was used to evaluate the importance where: $1=$ unimportant; $2=$ slightly important; 3 = important; $4=$ very important; $5=$ critical. An open 
space for comments or suggestions was given to the respondents at the end of the questionnaire.

Seventy (70) banking experts were asked to participate in the research study, and fifty one (51) from thirteen (13) banks in Serbia took part in it, resulting in the participation rate of $72.86 \%$ in both rounds of the Delphi. The expert group consisted of managers at three levels in the banking industry: first line management, middle management and top management. The first line management amounted to 24 respondents or $47 \%$, followed by the middle management amounting to 19 respondents or $37 \%$ and experts at the top management position amounting to 8 respondents or $16 \%$ of total participants.

Respondents provided information regarding years of management experience that were categorized from 0 to 3 years; from 3 to 6 , and from 6 to 9 and the final category was 9 or more years of management experience in banking. The largest group of managers had 9 or more years of banking experience, accounting for 17 experts or $33 \%$, followed by equal numbers and percentages of 3 to 6 and 6 to 9 years, accounting for 14 banking experts or $27 \%$ of all respondents, while only 6 experts had less than 3 years of banking experience, with $12 \%$ of participation rate.

The average importance rating, standard deviation and percentage level of importance for each evaluated determinant after round one and round two, were obtained using statistical calculation.

Finally, the most significant determinants recognized by banking experts in the Delphi survey, are classified for further evaluation through an AHP decision - making model in order to rank the determinants according to their significance for implementation of an open innovation concept in banking. The most significant determinants for further evaluation are presented in the Table 2.

In addition to the Delphi method, Cronbach's alpha test is used to estimate the reliability of results obtained from the Delphi research study. The reliability test was performed on the most significant determinants after the second round, consisting of fifteen elements. The reliability result obtained using Cronbach's Alpha test shows the value of 0.793 , indicating the scale of considerably reliable judgments. Therefore, experts' judgment on the choice of the most important alternatives for development of open innovation model is considered reliable and may be further evaluated through the AHP. 
Tornjanski V. et al.: The prioritization of open innovation determinants in banking

Table 2. The most significant determinants after the second round of the Delphi

\begin{tabular}{|c|c|}
\hline $\begin{array}{l}\text { The most significant determinants after II round of Delphi for further } \\
\text { evaluation }\end{array}$ & $\begin{array}{l}\text { Average } \\
\text { value (tn) }\end{array}$ \\
\hline \multicolumn{2}{|l|}{ Organizational context } \\
\hline $\begin{array}{l}\text { Formal reinforcement by management to integrate innovation into organizational } \\
\text { policies }\end{array}$ & 4.8627 \\
\hline $\begin{array}{l}\text { The extent to which the innovation fits into existing company's rules, regulations, } \\
\text { and legislations }\end{array}$ & 4.7843 \\
\hline $\begin{array}{l}\text { The degree of staff capacity in the organization or department that implements } \\
\text { the innovation }\end{array}$ & 4.7451 \\
\hline \multicolumn{2}{|l|}{ Business model and strategy } \\
\hline Building the ambidextrous organization & 4.4706 \\
\hline Strategic and operational flexibility and openness & 4.3922 \\
\hline Opportunity-driven business development & 4.2745 \\
\hline \multicolumn{2}{|l|}{ Leadership and culture } \\
\hline The platform of open innovation culture & 4.5294 \\
\hline The proactive role of innovation management & 4.4706 \\
\hline Developing a set of new management practices & 4.3529 \\
\hline \multicolumn{2}{|l|}{ Intellectual property (IP) } \\
\hline Development of intermediate IP markets & 4.4902 \\
\hline $\begin{array}{l}\text { Focus on IP generators and collaborators - external stakeholders such as } \\
\text { companies, public universities and R\&D institutions, users, customers, suppliers }\end{array}$ & 4.4510 \\
\hline Enhancing strategies for managing the intellectual property rights risk & 4.4314 \\
\hline \multicolumn{2}{|l|}{ Technology and infrastructure } \\
\hline Integrated banking system & 4.6863 \\
\hline Flexible service architecture / The flexible financial solution platforms & 4.4510 \\
\hline Enhancing technological competitiveness of products, processes, and service & 4.3333 \\
\hline
\end{tabular}

Source: Authors' calculation

\subsection{The application of the AHP method in the study}

The AHP is used here to prioritize the most significant determinants of open innovation in banking, previously selected by the Delphi method. The 
Tornjanski V. et al.: The prioritization of open innovation determinants in banking

research problem is decomposed into a hierarchy structure that includes the overall goal, five criteria and fifteen alternatives, as shown in Figure 1.

Figure1. Structured AHP hierarchy for development of open innovation model in banking

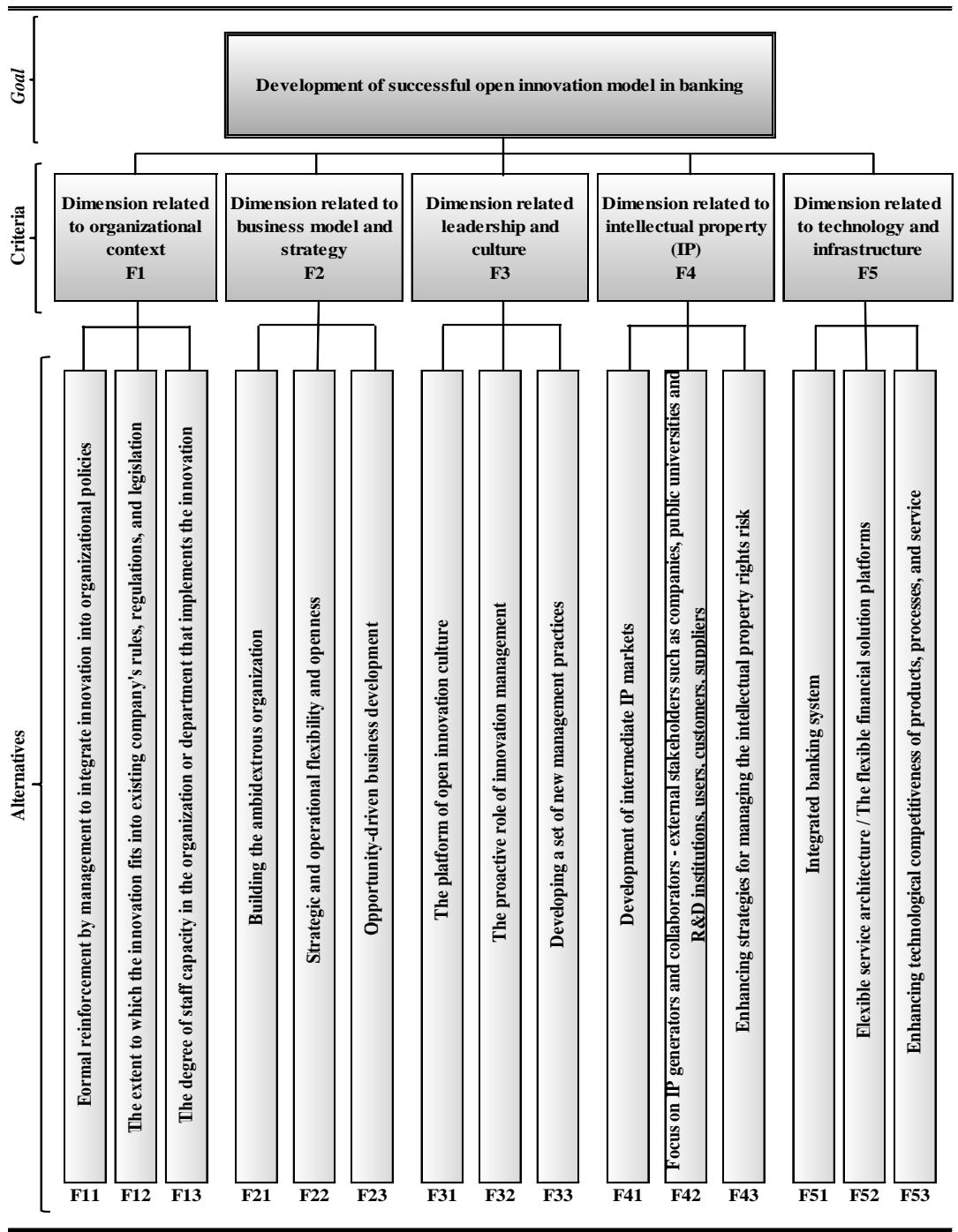

Source: Authors 
Once the structure of the problem has been designed, the prioritization of each element started in order to determine the relative importance of each. Prioritization procedure implies the comparison of elements (two by two) in regard to other elements at the same level and in regard to elements of the upper level of the hierarchy. The comparison is done by answering two questions: "which is more important" and "by how much", using the Saaty's scale of evaluation. A questionnaire survey was delivered to managers at the top level managerial position in banking in Serbia: CEO, CFO, CIO, COO, $\mathrm{CMO}$, (previously included in the Delphi study), with more than six years of banking experience.

Once all elements at both levels (Level 1 represents criteria, and Level 2 represents alternatives) were compared by experts, according to the AHP procedure, the matrices are constructed. The analysis of results further involves assigning the local weights according to the distributive way of calculation, resulting in a "priority vector" which enabled prioritizing of the best element in relation to the overall goal or related criteria. Consistency ratio was calculated to ensure the coherence of the judgments respectively. Consistency ratio of the pairwise comparison matrices at both levels is less than 0.10. Accordingly, the weights are shown to be consistent and the comparisons are acceptable.

\subsubsection{Results of Level 1 Evaluated criteria}

Table 3 shows the results of pairwise comparison of criteria against the overall goal.

Table 3. Judgment comparison matrix of criteria relative to the main goal

\begin{tabular}{|c|c|c|c|c|c|c|}
\hline \multicolumn{2}{|c|}{$\begin{array}{l}\text { Development of } \\
\text { successful open } \\
\text { innovation model } \\
\text { in banking }\end{array}$} & \multirow{2}{*}{$\begin{array}{c}\text { F1 } \\
\begin{array}{c}\text { Organizati } \\
\text { onal } \\
\text { context }\end{array} \\
1\end{array}$} & \multirow{2}{*}{$\begin{array}{c}\begin{array}{c}\text { F2 } \\
\text { Busines } \\
\text { s model } \\
\text { and } \\
\text { strategy }\end{array} \\
3 \\
\end{array}$} & \multirow{2}{*}{$\begin{array}{c}\text { F3 } \\
\text { Leadershi } \\
\text { p and } \\
\text { culture }\end{array}$} & \multirow{2}{*}{$\begin{array}{c}\text { F4 } \\
\text { Intellectu } \\
\text { al } \\
\text { property } \\
\text { (IP) } \\
4\end{array}$} & \multirow{2}{*}{$\begin{array}{c}\text { F5 } \\
\begin{array}{c}\text { Technology and } \\
\text { infrastructure }\end{array} \\
3 \\
\end{array}$} \\
\hline $\mathrm{F} 1$ & $\begin{array}{l}\text { Organizational } \\
\text { context }\end{array}$ & & & & & \\
\hline $\mathrm{F} 2$ & $\begin{array}{l}\text { Business model } \\
\text { and strategy }\end{array}$ & $1 / 3$ & 1 & 5 & 2 & 2 \\
\hline F3 & $\begin{array}{l}\text { Leadership and } \\
\text { culture }\end{array}$ & $1 / 5$ & $1 / 5$ & 1 & $1 / 2$ & $1 / 5$ \\
\hline $\mathrm{F} 4$ & $\begin{array}{l}\text { Intellectual } \\
\text { property (IP) }\end{array}$ & $1 / 4$ & $1 / 2$ & 2 & 1 & $1 / 3$ \\
\hline F5 & $\begin{array}{l}\text { Technology and } \\
\text { infrastructure }\end{array}$ & $1 / 3$ & $1 / 2$ & 5 & 3 & 1 \\
\hline
\end{tabular}

Source: Authors' calculation 
Table 4 illustrates the calculation of results that includes assigning the local weights according to the distributive way of calculation, resulting in the prioritization of criteria at Level 1 for successful development of open innovation model in banking.

Table 4. Vector of eigenvalues of comparison matrix and weight calculation based on Saaty's eigenvector procedure for criteria at Level 1 relative to the overall goal

\begin{tabular}{ccccccccc}
\hline $\begin{array}{c}\text { With } \\
\text { respect } \\
\text { to the } \\
\text { main goal }\end{array}$ & F1 & F2 & F3 & F4 & F5 & $\sum \mathbf{a}^{*} \mathbf{i j}$ & Weights & $\begin{array}{c}\text { Priority } \\
\text { vector }\end{array}$ \\
\hline F1 & 0.4739 & 0.5769 & 0.2778 & 0.3810 & 0.4594 & 2.1690 & 0.4338 & $\mathbf{4 3 . 3 8 \%}$ \\
F2 & 0.1564 & 0.1923 & 0.2778 & 0.1905 & 0.3063 & 1.1232 & 0.2246 & $\mathbf{2 2 . 4 6 \%}$ \\
F3 & 0.0948 & 0.0385 & 0.0556 & 0.0476 & 0.0306 & 0.2671 & 0.0534 & $\mathbf{5 . 3 4 \%}$ \\
F4 & 0.1185 & 0.0962 & 0.1111 & 0.0952 & 0.0510 & 0.4720 & 0.0944 & $\mathbf{9 . 4 4 \%}$ \\
F5 & 0.1564 & 0.0962 & 0.2778 & 0.2857 & 0.1531 & 0.9692 & 0.1938 & $\mathbf{1 9 . 3 8 \%}$ \\
\hline
\end{tabular}

Source: Authors' calculation

Priority of criteria at Level 1 relative to the main goal is as follows: F1 - F2 - F5 - F4 - F3. Based on the expert assessments, the highest priority in the implementation of the open innovation model in banking refers to the dimension related to organizational context $(w=0.4338)$, followed by the category related to business model and strategy $(\mathrm{w}=0.2246)$. The third priority is that of the technology and infrastructure dimension $(w=0.1938)$. Next priority goes to the factors that involve intellectual property $(w=0.0944)$. The dimension with the lowest degree, according to the results, refers to leadership and culture $(w=0.0534)$.

The result of consistency ratio is 0.068 , indicating that the judgment comparison of criteria in relation to the main goal is acceptable.

\subsubsection{Results of Level 2 Evaluated alternatives}

Having the results of pairwise comparison of determinants in respect to the corresponding criteria, local weights were calculated at Level 2 following the same steps for each matrix for the Level 1 . Table 5 depicts a summary of calculated priorities of criteria, priorities of determinants within the corresponding criteria and the overall priority of the determinants towards the main goal. The results of calculated consistency ratio of determinants at Level 2 are also presented in table. 
Tornjanski V. et al.: The prioritization of open innovation determinants in banking

Table 5. Summarized priorities and consistency ratios of comparisons of the criteria and determinants

\begin{tabular}{|c|c|c|c|c|c|c|}
\hline Criteria & $\begin{array}{l}\text { Priority } \\
\text { vector } \\
\text { of } \\
\text { criteria } \\
\end{array}$ & Determinants & $\begin{array}{l}\text { Consistency } \\
\text { ratio }\end{array}$ & $\begin{array}{l}\text { Priority } \\
\text { vector } \\
\text { within the } \\
\text { criteria } \\
\end{array}$ & $\begin{array}{c}\text { Overall } \\
\text { priority } \\
\text { values of the } \\
\text { determinants }\end{array}$ & $\begin{array}{l}\text { Final } \\
\text { priority }\end{array}$ \\
\hline \multirow[t]{3}{*}{$\begin{array}{l}\text { Organizational } \\
\text { context }\end{array}$} & 0.4338 & $\begin{array}{l}\text { F11 - Formal reinforcement } \\
\text { by management to integrate } \\
\text { innovation } \\
\text { organizational policies }\end{array}$ & \multirow[t]{3}{*}{0.040} & 0.6340 & 0.2750 & 1 \\
\hline & & $\begin{array}{l}\text { F12 - The extent to which } \\
\text { the innovation fits into } \\
\text { existing company's rules, } \\
\text { regulations, and legislation }\end{array}$ & & 0.1060 & 0.0460 & 7 \\
\hline & & $\begin{array}{l}\text { F13 - The degree of staff } \\
\text { capacity in the organization } \\
\text { or department that } \\
\text { implements the innovation }\end{array}$ & & 0.2600 & 0.1128 & 3 \\
\hline \multirow[t]{3}{*}{$\begin{array}{l}\text { Business } \\
\text { model and } \\
\text { strategy }\end{array}$} & 0.2246 & $\begin{array}{l}\text { F21 - Building the } \\
\text { ambidextrous organization }\end{array}$ & \multirow[t]{3}{*}{0.090} & 0.7242 & 0.1627 & 2 \\
\hline & & $\begin{array}{lcc}\text { F22 - } & \text { Strategic } & \text { and } \\
\text { operational } & \text { flexibility } & \text { and } \\
\text { openness } & & \end{array}$ & & 0.0825 & 0.0185 & 12 \\
\hline & & $\begin{array}{l}\text { F23 - Opportunity-driven } \\
\text { business development }\end{array}$ & & 0.1933 & 0.0434 & 8 \\
\hline \multirow[t]{3}{*}{$\begin{array}{l}\text { Leadership } \\
\text { and culture }\end{array}$} & 0.0534 & $\begin{array}{l}\text { F31 - The platform of open } \\
\text { innovation culture }\end{array}$ & \multirow[t]{2}{*}{0.040} & 0.6340 & 0.0339 & 9 \\
\hline & & $\begin{array}{l}\text { F32 - The proactive role of } \\
\text { innovation management }\end{array}$ & & 0.2600 & 0.0139 & 13 \\
\hline & & $\begin{array}{l}\text { F33 - Developing a set of } \\
\text { new management practices }\end{array}$ & & 0.1060 & 0.0057 & 15 \\
\hline \multirow[t]{4}{*}{$\begin{array}{l}\text { Intellectual } \\
\text { property (IP) }\end{array}$} & 0.0944 & $\begin{array}{l}\text { F41 - Development of } \\
\text { intermediate IP markets }\end{array}$ & \multirow[t]{4}{*}{0.070} & 0.6393 & 0.0604 & 5 \\
\hline & & $\begin{array}{l}\text { F42 - Focus on IP } \\
\text { generators and collaborators } \\
\text { - external stakeholders such }\end{array}$ & & & & \\
\hline & & $\begin{array}{lr}\text { as companies, public } \\
\text { universities and } & \text { R\&D } \\
\text { institutions, } & \text { users, } \\
\text { customers, suppliers } & \end{array}$ & & 0.2730 & 0.0258 & 10 \\
\hline & & $\begin{array}{l}\text { F43 - Enhancing strategies } \\
\text { for managing the intellectual } \\
\text { property rights risk }\end{array}$ & & 0.0877 & 0.0083 & 14 \\
\hline \multirow[t]{3}{*}{$\begin{array}{l}\text { Technology } \\
\text { and } \\
\text { infrastructure }\end{array}$} & 0.1938 & $\begin{array}{l}\text { F51 - Integrated banking } \\
\text { system }\end{array}$ & \multirow[t]{3}{*}{0.002} & 0.1093 & 0.0212 & 11 \\
\hline & & $\begin{array}{l}\text { F52 - Flexible service } \\
\text { architecture / The flexible } \\
\text { financial solution platforms }\end{array}$ & & 0.5815 & 0.1127 & 4 \\
\hline & & $\begin{array}{l}\text { F53 - Enhancing } \\
\text { technological } \\
\text { competitiveness of products, } \\
\text { processes, and service }\end{array}$ & & 0.3093 & 0.0599 & 6 \\
\hline
\end{tabular}

Source: Authors' calculation

Industrija, Vol.43, No.3, 2015 
According to the obtained results, the first priority in effective application of open innovation in banking lies in formal reinforcement by management to integrate innovation into organizational policies with priority vector of $27.50 \%$. In this way, open innovation activities and processes can be simultaneously strengthened within an organization, effective managed, tracked and properly measured as a core value in an organization's development and growth. Next, experts in banking in Serbia are of the opinion that an organization's ability to perform two different things at the same time with a focus on designing dual structures that facilitate the initiation and implementation of an innovation, i.e. building an ambidextrous organization, has the second priority with the overall ranking of $16.27 \%$ towards the main goal. The third priority belongs to the alternative related to the degree of staff capacity of an organization or department that implements the innovation, with percentage priority of $11.28 \%$. Flexible service architecture / the flexible financial solution platforms is in the fourth place of priority, with $11.27 \%$, while development of intermediate intellectual property markets results in the priority of $6.04 \%$. These first five alternatives accounts for $72.36 \%$ of total ranked alternatives.

On the other hand, enhancing technological competitiveness of products, processes, and services followed by alternatives related to the extent to which the innovation fits into existing company's rules, regulations, and legislations; opportunity-driven business development; the platform of open innovation culture; focus on IP generators and collaborators; integrated banking system; strategic and operational flexibility and openness; the proactive role of innovation management; enhancing strategies for managing the intellectual property rights risk and developing a set of new management practices, have a lower priority degree in the accomplishment of the main goal in the AHP.By entering European banks at the financial market, leadership and organizational culture have begun to radically change within the banks in Serbia. Dynamic business environment had a strong impact on leadership style and employees profile that resulted in fast changes in management practices, organizational culture and employees, making them more dynamic, open, and trustworthy with strong team spirit. Accordingly, these determinants had a lower priority degree in the assessment process. This, however, certainly does not mean that the alternatives with the lower priority degree should be neglected, taking into account their relevance in the development of open innovation in the banking industry. Effective application of open innovation in banking is dynamic and complex process that requires different priorities according to the going organizational situation and conditions at the external business environment. 
Tornjanski V. et al.: The prioritization of open innovation determinants in banking

\section{Conclusion}

This study explores determinants of the open innovation in the banking industry with an original approach. The introduction of open innovation in the banking industry is a complex process which implies identification and prioritization of the most significant determinants of open innovation in order to facilitate decision making in the selection of appropriate strategies towards successful implementation of open innovation in banking. Delphi and AHP research methods were used in this paper to identify and prioritize these determinants. Sixty one of them were obtained from the broader literature overview and grouped into eight dimensions. A two-round Delphi method was performed to achieve consensus among fifty one experts from the banking industry to recognize the most significant elements for further evaluation. In addition, the results of the Delphi method were tested using Cronbach's alpha test to confirm the reliability of the given results of the Delphi method. Fifteen significant determinants within five dimensions were further evaluated through the AHP decision-making method to prioritize them toward the development of the open innovation in banking.

The results of the AHP study showed that the first priority in effective application of open innovation in banking lies in the formal reinforcement by management to integrate innovation into organizational policies with priority vector of $27.50 \%$, building an ambidextrous organization, has the second priority, $16.27 \%$, degree of staff capacity $11.28 \%$, flexible service architecture I the flexible financial solution platforms $11.27 \%$, while development of intermediate intellectual property markets results in the priority of $6.04 \%$. These first five alternatives accounts for $72.36 \%$ of total ranked alternatives. This, however, does not mean that the alternatives with the lower priority degree should be neglected, taking into account their relevance in the development of open innovation in the banking industry.

Finally, the study acknowledges potential limitations despite the relevance of the obtained results in terms of the development of open innovation in the banking industry. One limitation of the research study is the participation of only one group of stakeholders, i.e. banking experts in Serbia. Different stakeholder groups may have different views, requirements, constraints and motivations related to the implementation of open innovation in banking. Although experts from banking are the most relevant stakeholder group, stakeholders such as customers, universities, regulatory bodies, shareholders may recognize different significant factors and their prioritization in the implementation of the concept in banking. Another limitation of the research paper is the focus on the participants from only one country. That is, the study results may not be directly applicable to each and every other country. 
The research findings and results introduced in this paper can be usefully applied and widely used by both academics and practitioners who are interested in applying the open innovation concept in the service industry, or more specifically, in the banking industry. This paper also contributes to the theoretical work and thoughts in the field of innovation management.

Future research on the development of open innovation in banking should incorporate perspectives from different stakeholder group, i.e. academics and other interested groups. Moreover, the results should be compared with the research results from other countries. These insights may reveal additional useful information regarding the implementation of open innovation in the banking industry. Proposed evaluation model could be applied in other industries in order to determine important determinants when implementing new business models.

\section{References}

Adler, M., \& Erio, Z. (1996). Gazing into the oracle: The Delphi method and its application to social policy and public health. Jessica Kingsley Publishers.

Alguezaui, S., \& Filieri, R. (2010). Investigating the role of social capital in innovation: Sparse versus dense network. Journal of knowledge management, 14(6), 891909.

Alonso, J. A., \& Lamata, M. T. (2006). Consistency in the analytic hierarchy process: A new approach. International Journal of Uncertainty, Fuzziness and KnowledgeBased Systems, 17(4), 445-459.

Arslan, T. (2009). A hybrid model of fuzzy and AHP for handling public assessments on transportation projects. Transportation, 36(1), 97-112.

Bahemia, H., \& Squire, B. S. (2010). Managing open innovation at a project level, a dynamic managerial capability perspective. In: DRUID 2011, Copenhagen Business School, Denmark. 1-21.

Bellantuono, N., Pontrandolfo, P., \& Scozzi, B. (2013). Different practices for open innovation: a context-based approach. Journal of Knowledge Management, 17(4), 558-568.

Bhuasiri, W., Xaymoungkhoun, O., Zo, H., Rho, J. J., \& Ciganek, A. P. (2012). Critical success factors for e-learning in developing countries: A comparative analysis between ICT experts and faculty. Computers \&; Education, 58(2), 843-855.

Bughin, J., Chui, M., \& Johnson, B. (2008). The next step in open innovation. McKinsey Quarterly, 4(6), 1-8.

Chen, C. F. (2006). Applying the analytical hierarchy process (AHP) approach to convention site selection. Journal of Travel Research, 45(2), 167-174.

Chesbrough, H., \& Appleyard, M. (2007). Open innovation and strategy. California Management Review, 50(1), 57-73.

Chesbrough, H. (2006). Open innovation: a new paradigm for understanding industrial innovation. Open innovation: Researching a new paradigm, 1-12.

Chesbrough, H. (2007). Business model innovation: it's not just about technology anymore. Strategy \& Leadership, 35(6), 12-17. 
Tornjanski V. et al.: The prioritization of open innovation determinants in banking

Chesbrough, H. (2010). Business model innovation: Opportunities and barriers. Long range planning, 43(2), 354-363.

Chesbrough, H.W. (2003). The era of open innovation. MIT Sloan Management Review, 44(3), 35-41.

Chesbrough, H. W. (2003). Open Innovation: The New Imperative for Creating and Profiting from Technology. Harvard Business Press.

Chesbrough, H., Vanhaverbeke, W., \& West, J. (2006). Open Innovation: Researching a New Paradigm. Oxford University Press.

Chiaroni, D., Chiesa, V., \& Frattini, F. (2011). The Open Innovation Journey: How firms dynamically implement the emerging innovation management paradigm. Technovation, 31(1), 34-43.

Christensen, C. M. (1997). The innovator's dilemma: When new technologies cause great firms to fail. Harvard Business Press.

Cooke, P. (2013). Exploring Knowledge-Intensive Business Services: Knowledge Management Strategies. European Planning Studies, 21(1), 112-114.

Dahlander, L., \& Gann, D.M. (2010). How open is innovation. Research Policy, 39(6), 699-709.

de Felice, F., \& Petrillo, A. (2010). A new multicriteria methodology based on Analytic Hierarchy Process: the "Expert" AHP. International Journal of Management Science and Engineering Management, 5(6), 439-445.

Dodgson, M., Gann, D., \& Salter, A. (2006). The role of technology in the shift towards open innovation: The case of Procter \&; Gamble. R\&D Management, 36(3), 333346.

Domański, C., \& Kondrasiuk, J. (2005). Analytic Hierarchy Process: Applications in Banking. In Innovations in Classification, Data Science, and Information Systems. (pp. 435-445).

Drucker, P.F. (1988). The Coming of the New Organization. Harvard Business Review.

Elmquist, M., Fredberg, T., \& Ollila, S. (2009). Exploring the field of open innovation. European Journal of Innovation Management, 12(3), 326-345.

Enkel, E., \& Gassmann, O. (2007). Driving Open Innovation in the Front End: the IBM Case. In: EURAM Conference, Paris.

Enkel, E., Gassmann, O. \& Chesbrough, H. (2009). Open R\&D and open innovation: Exploring the phenomenon. R\&D Management, 39(4), 311-316.

Fasnacht, D. (2009). Open Innovation in the financial services: Growing through openness, flexibility and customer integration. Springer.

Fredberg, T., Elmquist, M., \& Ollila, S. (2008). Managing Open Innovation: Present Findings and Future Directions. In Vinnova Report VR.

Frei, F. X., Harker, P.T., \& Hunter, L.W. (1997). Innovation in retail banking. In Conference on America's Industrial Resurgence: Sources and Prospects. Draft manuscript.

Gassmann, O. (2006). Opening up the innovation process: Towards an agenda. R\&D Management, 36(3), 223-228.

Gassmann, O. \& Enkel, E. (2004). Towards a theory of open innovation: Three core process archetypes. In: R\&D management conference. 1-18.

Gassmann, O., Enkel, E., \& Chesbrough, H. (2010). The future of open innovation. $R \& D$ Management, 40(3), 213-221.

Handfield, R., Walton, S. V., Sroufe, R., \& Melnyk, S. A. (2002). Applying environmental criteria to supplier assessment: A study in the application of the 
Tornjanski V. et al.: The prioritization of open innovation determinants in banking

Analytical Hierarchy Process. European Journal of Operational Research, 141(1), 70-87.

Harker, P. T., \& Vargas, L.G. (1987). The Theory of Ratio Scaled Estimated: Saaty's Analytical Hierarchy Process. Management Science, 33(11), 385-403.

Heertje, A., \& Perlman, M. (1991). Evolving technology and market structure: Studies in Schumpeterian economics. University of Michigan Press.

Huff, A. S., Slein, K. M., \& Reichwald, R. (2013). Leading Open Innovation. MIT Press (MA).

Huizingh, E. K. (2011). Open innovation: State of the art and future perspectives. Technovation, 31(1), 2-9.

Huo, J., \& Hong Z. (2013). The Rise of Service Science. In Service Science in China. Berlin Heidelberg: Springer.

Koschatzky, K. (2001). Networks in innovation research and innovation policy: An introduction. In: Conference on Innovation Networks: Concepts and Challenges in the European Perspective, Heidelberg: Physica Verlag.

Krishnan, P. V., Ramnath, B.V., \& Pillai, M.K. (2012). Mathematical Model Using AHP to optimize the Organizational Financial Performance. In: Ninth AIMS International Conference on Management.

Laursen, K., \& Salter, A.J. (2006). Open for innovation: The role of openness in explaining innovation performance among UK manufacturing firms. Strategic Management, 27(2), 131-150.

Leire, S.J., Retolaza, J.L., Urionabarrenetxea, S., Ruiz-Roqueñi, M., \& Azkunaga, J. A. (2013). The New Paradigm of Corporate Finance: Ethics in Finance, ICTs, Financial Globalization and Stakeholder Responsibility. International Research Journal of Finance and Economics, 103(1), 191-206.

Luftenegger, E., Angelov, S., van der Linden, E., \& Grefen, P. W. P. J. (2010). The state of the art of innovation-driven business models in the financial services industry. Beta Report. Eindhoven University of Technology.

Luthans, F., \& Doh, J. P. (2011). International Management, 8th ed., McGraw-Hill.

Marinkovic, S., Levi-Jaksic, M., \& Manic, B. (2011). Service innovations based on ICT implementation: Roles of NSD participants. Technics Technologies Education Management-TTEM, 6(2), 438-446.

Martins, E. C., \& Terblanche, F. (2003). Building organisational culture that stimulates creativity and innovation. European journal of innovation management, 6(1), 6474.

Mihailovic, N., Bulajic, M., \& Savic, G. (2009). Ranking of banks in Serbia. Yugoslav Journal of Operations Research, 19(2), 323-334.

Mol, M. J., \& Birkinshaw, J. (2009). The sources of management innovation: When firms introduce new management practices. Journal of business research, 62(12), 1269-1280.

NBS. (2013). Annual financial stability report. Retrieved from http://nbs.rs/export/sites/default/internet/latinica/90/90_2/finansijska_stabilnost_2 013.pdf

OECD. (2008). OECD in figures. Paris, France: OECD Publications.

Okoli, C., \& Pawlowski, S.D. (2004). The Delphi method as a research tool: an example, design considerations and applications. Information \& Management, 42(1), 15-29.

Peng, K. L., Lin, M. C., \& Baum, T. (2013). The constructing model of culinary creativity: An approach of mixed methods. Quality \& Quantity, 47(5), 2687-2707. 
Rogers, E. M. (1995). Diffusion of innovations. Simon and Schuster.

Saaty, T. L. (1980). The Analytic Hierarchy Process. New York: McGraw-Hill. Book Co. Saaty, T.L. (1986). Axiomatic Foundation of the Analytic Hierarchy Process. Management Science, 32(1), 841-855.

Sari, B., Sen, T., \& Kilic, S.E. (2008). Ahp model for the selection of partner companies in virtual enterprises. International Journal of Advanced Manufacturing Technology, 38(3-4), 367-376.

Sarros, J.C., Cooper, B. K., \& Santora, J.C. (2008). Building a climate for innovation through transformational leadership and organizational culture. Journal of Leadership \& Organizational Studies, 15(2), 145-158.

Schmitt, R., Humphrey, S., \& Köhler, M. (2013). EMOTIO: Systematic Customer Integration into the Process of Innovation. In: Future Trends in Production Engineering. (pp. 241-250). Berlin Heidelberg: Springer.

Skulmoski, G. J., Hartman, F.T., \& Krahn, J. (2007). The Delphi method for graduate research. Journal of information technology education, 6(1), 1-21.

Sundbo, J. (2003). Innovation and strategic reflexivity: An evolutionary approach applied to services. In The International Handbook on Innovation. (pp. 97-114).

Taleai, M., \& Mansourian, A. (2008). Using Delphi-AHP method to survey major factors causing urban plan implementation failure. Journal of applied sciences, 8(15), 2746-2751.

Teece, D. J. (2010). Business models, business strategy and innovation. Long range planning, 43(2), 172-194.

Tornjanski, V., Marinković, S., \& Lalić, N. (2014). Application of ANP method based on a BOCR model for decision-making in banking. In: XIV international symposium SYMORG New business models and sustainable competitiveness. FON.

van de Vrande, V., de Jong, J. P., Vanhaverbeke, W., \& De R. M. (2009). Open innovation in SMEs: Trends, motives and management challenges. Technovation, 29(6), 423-437.

Wallin, M. W., \& Von Krogh, G. (2010). Organizing for Open Innovation: Focus on the Integration of Knowledge. Organizational Dynamics, 39(2), 145-154.

Walter, I. (2009). Economic drivers of structural change in the global financial services industry. Long Range Planning, 42(5), 588-613.

West, J., \& Gallagher, S. (2006). Challenges of open innovation: The paradox of firm investment in open-source software. $R$ \& D Management, 36(3), 319-331.

West, J., \& Gallagher, S. (2006). Patterns of open innovation in open source software. Open Innovation: researching a new paradigm, 235(11).

Wiengarten, F., Humphreys, P., Mckittrick, A., \& Fynes, B. (2013). Investigating the impact of e-business applications on supply chain collaboration in the German automotive industry. International Journal of Operations \& Production Management, 33(1), 25-48.

World Trade Organization. (2013). Retrieved from: http://www.wto.org/english/news e/pres01 e/pr208 e.htm

Zott, C., Amit, R., \& Massa, L. (2011). The business model: recent developments and future research. Journal of management, 37(4), 1019-1042. 